\title{
THE MECHANISMS FOR PROVIDING THE INNOVATION OF THE TOURISM SPHERE OF THE REGION IN THE CONDITIONS OF SUSTAINABLE DEVELOPMENT
}

\section{МЕХАНІЗМИ ЗАБЕЗПЕЧЕННЯ ІННОВАЦІЙНОСТІ ТУРИСТИЧНОЇ СФЕРИ РЕГІОНУ В УМОВАХ СТАЛОГО РОЗВИТКУ}

\author{
Maria Lushchyk ${ }^{1}$ \\ Oksana Roik ${ }^{2}$
}

DOI: https://doi.org/10.30525/978-9934-588-53-2-7

Abstract.The paper substantiates theoretical and practical bases on the formation of mechanisms for providing the innovation of the tourism sphere of the region in the conditions of sustainable development. This mechanism is considered as a strategic priority of socio-economic development of the Ukrainian regions. The work sets out the priority areas for tourism development, which will provide that socio-economic development will be largely supported by innovative tourism development. The purpose of the work is the development of theoretical and methodological provisions, methodological foundations and practical recommendations on the formation of mechanisms for providing innovation tourism sphere of the region in terms of sustainable development as a strategic one priority of socioeconomic development of regions of Ukraine. The study has found that the aggravation of crisis phenomena in the field of tourism and resorts suggests the need to improve state and regional policy in this area, priorities and principles of its implementation, powers and competences of tourism actors, the introduction of effective organizational, legal, economic, informational mechanisms of development of tourism and resorts as a highly profitable sector of the national economy. The study justifies measures to improve the quality and competitiveness of the tourism product and to implement an effective policy aimed at promoting the tourism sphere of the region.

\footnotetext{
${ }^{1}$ Candidate of Geographical Sciences, Associate Professor,

National University «Lviv Polytechnic», Ukraine

${ }^{2}$ Candidate of Economic Scinces, Associate Professor,

National University «Lviv Polytechnic», Ukraine

(C) Maria Lushchyk, Oksana Roik
} 
Implementation of the mechanism of providing the innovation of the tourism sphere of the region in the conditions of sustainable development, as a basic element, will provide the achievement of the goals and the objectives of the strategy of innovative development of tourism. On the basis of the theory and methodology of regional development, the new management system for innovative development of the tourism industry has been grounded in order to move to a new doctrine of socio-economic standards of regional growth, which provides a basis for transition to new mechanisms for realization of the regional policy of development of tourism and recreation in unstable socioeconomics conditions.

\section{Introduction}

Tourism as an important component of socio-economic development of the national economy, contributes to job creation, activates the business sector, provides significant revenues to the state budget [4]. On this basis, the study of tourism innovation is impossible without innovative development and innovation policy, which determines its innovative transformation, and therefore requires a clear delineation of promising ways to apply social innovations, development of specific measures and technologies for their practical implementation, methods of evaluation, taking into account main priorities of sustainable development.

The strategic goal of economic transformations, which are still taking place in Ukraine, is the formation of mechanisms for tourism innovation in the context of sustainable development, which is impossible without a comprehensive analytical study of the conditions and results of balanced socio-economic and innovative transformations.

The variety of tourist and recreational resources, favorable natural and climatic conditions, staffing potential are all favorable conditions for the formation of sustainable tourism development at the international and regional levels. However, the transformation processes taking place in the socio-economic sphere of Ukraine require revision and improvement of the management of socio-economic development of the country through the transformation of the domestic economy in general, as well as a number of priority industries in tourism in particular.

The development of tourism has been the subject of analysis by many scientists, including L. Ahafonova, O. Beidyk, Z. Herasymchuk, H. Horina, 
H. Ilnytska, O. Liubintseva, M. Malska, A. Terebukha, etc. Innovative aspects of tourism activity have partially been studied in the works of such scientists as M. Lushchyk, O. Makary, A. Melnyk, O. Stefanyshyn, H. Trillenberg, L. Fedulova, Ya. Orlenko, N. Moisieieva, O. Davydova, etc. Research on the impact of innovation on tourism development has not been properly treated, as well as the development of new mechanisms for introducing innovation in the tourism industry, and requires further research.

The main purpose of the study is the research of theoretical and methodological features of the need to introduce innovation in the tourism sphere as one of the main factors of sustainable socio-economic development of the region.

\section{General overview of tourism development in Ukraine}

For a number of countries, tourism has become one of the main patterns of development of the national economy. The development of tourism is now determined by a factor that contributes to the stabilization of society and increase of the economic efficiency. In this context, the problems of theoretical and methodological analysis of innovation in tourism, identifying its importance in the socially oriented process of social reproduction, and integrated assessment of the place and role of innovation factors in sustainable tourism in particular.

According to the data of the World Economic Forum [12] on the calculation of the Tourism Competitiveness Index, conducted in 2019, Ukraine took 78th place, gaining 3.7 points out of 7 . The leaders in this index were Spain, France, Germany, the United States and Japan, scoring an average of 5.4 points each. While the lowest rates were in Yemen 2.4, Chad -2.5 and Liberia - 2.6. The analysis of the coefficients in the Travel and Tourism Competitiveness Index of Ukraine showed the growth of indicators that characterized the potential for socio-economic growth. However, the main indicators of tourism development (Table 1) show some improvement in the dynamics not due to innovative factors, which indicates the formation of negative trends in the country: innovations have not had a significant impact on socio-economic growth both in the country and in the tourism sphere in particular

According to the analysis of the data in Table 1, the key indicators of tourism activity in Ukraine are quite low and have a downward trend. Thus, 
Table 1

Key indicators of tourism development in Ukraine

\begin{tabular}{|l|c|c|c|c|c|}
\hline \multicolumn{1}{|c|}{ Indicators } & $\mathbf{2 0 1 4}$ & $\mathbf{2 0 1 5}$ & $\mathbf{2 0 1 6}$ & $\mathbf{2 0 1 7}$ & $\mathbf{2 0 1 8}$ \\
\hline $\begin{array}{l}\text { Tourism, total contribution } \\
\text { to GDP (share, \%) }\end{array}$ & 5.5 & 5.4 & 5.4 & 5.6 & 5.4 \\
\hline $\begin{array}{l}\text { Number of arrivals } \\
\text { (million people) }\end{array}$ & 24.671 & 12.712 & 12.428 & 13.333 & 14.230 \\
\hline $\begin{array}{l}\text { Number of departures } \\
\text { (million people) }\end{array}$ & 23.761 & 22.438 & 23.142 & 24.668 & 26.437 \\
\hline $\begin{array}{l}\text { Revenues from tourism } \\
\text { (million USD) }\end{array}$ & 5931 & 2264 & 1662 & 1723 & 1999 \\
\hline $\begin{array}{l}\text { Expenses from tourism } \\
\text { (million USD) }\end{array}$ & 5763 & 5061 & 5101 & 5970 & 7128 \\
\hline $\begin{array}{l}\text { Total contribution of } \\
\text { tourism to employment } \\
\text { (share, \%) }\end{array}$ & 6.8 & 4.8 & 4.9 & 5.0 & 4.9 \\
\hline $\begin{array}{l}\text { Investment in tourism } \\
\text { (billion USD) }\end{array}$ & 0.4 & 0.3 & 0.3 & 0.3 & 0.4 \\
\hline
\end{tabular}

Source: developed by the author according to [11]

the total contribution of tourism to GDP remains extremely low, given the significant tourism and recreational potential of the country, and decreased slightly from $5.5 \%$ in 2014 to $5.4 \%$ in 2018 ; the number of arrivals decreased during 2014-2018 (from 24.7 million people in 2014 to 14.2 million people in 2018); during this period there was a slight increase in the number of departures in $2014-23.8$ million people and up to 26.4 million people in 2018; revenues from tourism decreased by almost half - from 5931 million USD in 2014 to 1999 million USD in 2019; the total contribution of tourism to employment also decreased to $4.9 \%$ in 2018 (as opposed to $6.8 \%$ in 2014).

Ukraine has not adopted a Tourism Strategy and Development Plan 2016-2020, and has not developed a Tourism Development Program in accordance with the Sustainable Development Strategy "Ukraine 2020". Due to the optimization and saving of budget funds in 2014, the Concept of the State Target Program for the Development of Tourism and Resorts for the period up to 2022 has expired [4]. Thus, in Ukraine, the tourism industry is developing without clearly defined strategic guidelines and development targets. Solving these problems requires a clear delineation of promising ways to apply innovations, development of specific measures 
and technologies for their practical implementation, creation of methods for their evaluation in the context of forming mechanisms to provide innovation in the tourism sphere in sustainable development.

\section{Formation of a mechanism to provide the innovation of tourism in the region}

Special attention should be paid to such key factors of innovative development as educational, qualification and intellectual potential of society, the degree of social differentiation, principles and directions of income policy implementation. Innovative strategies, concepts, ideas as tools of innovative transformation should be the basis of the mechanism of stimulating innovative development of the tourism sphere [2]. The implementation of such a mechanism requires a clear delineation of promising ways to apply social innovations, the development of specific measures and technologies for their practical implementation, the creation of methods for their evaluation.

Innovation in tourism should be considered the result, implemented products or services based on the creation, implementation and realiztion of innovations in various sectors of the economy, including tourism, and aimed at increasing living standards and creating conditions for human development [7].

The concept of «innovation» [9] is a relatively new phenomenon for the Ukrainian economics, which, on the one hand, is based on the willingness to create, implement and realize innovations in various sectors of the economy and social life, aimed at creating conditions for a dignified life and development, as well as harmonious relations with the environment.

As for innovations in tourism in a broad sense, these are primarily changes in tourism, which are initiated on the basis of scientific knowledge, aimed at improving the standard and quality of life and have a high dependence on group and personal qualities of users [9, p. 55].

In the strict sense, innovation in tourism is a general process of systematic improvement of the tourism sphere, aimed at expanding the capacity of one of the areas of action to achieve strategic goals, which, in turn, strengthens confidence in social obligations to society as a whole.

The use of the term "mechanism" in an attempt to improve the management process is due to its content. In a general sense, it means "a 
system that determines the order of a particular activity" and characterizes the "sequence of states and processes that make up any action" [6].

The essence of the concept of a mechanism is reflected in the views of scientists. A. Melnyk defines it as a set of forms and methods of regulating economic processes [2]. H. Ilnytska [4] defines this concept as a part of the economic mechanism, which includes methods and tools for regulating economic relations and processes. I. Tsyhlyk [11, p. 14] believes that the economic mechanism is a set of economic methods and levers that regulate the activities of the team in order to achieve economic and social goals.

It can be argued that in general the mechanism is considered by domestic scientists $[4 ; 7 ; 12]$ as a system of measures (interconnected and interdependent) of different nature, through which it provides proper implementation of innovation in tourism in accordance with established principles. This mechanism will be formed on the basic principles of the concept of sustainable tourism and environmentally friendly tourism policy. It is important to note the regional specifics of the formation of sustainable development, taking into account the specific properties and conditions in each region. At the regional level, the implementation of this mechanism will effectively use the natural resource potential, overcoming the existing negative social, economic and environmental situation in the region, as well as provide the achievement of goals, objectives and areas of tourism development [6].

Thus, it can be argued that the constituent elements of the mechanism should be considered as a system of an integrated whole, linked by social, economic and environmental ties, and include a regulatory and institutional mechanism (created on the basis of legal regulation of tourism and providing favorable legal framework in the field of tourism), organizational and management mechanism (aimed at improving strategic planning and management of tourism development), financial and economic mechanism (includes the development of a tax system for tourism enterprises, the provision of tax benefits, grants and subsidies for investment projects), information and communication mechanism (focused on promoting tourism in the international tourism market, forming a positive image of tourism and recreation in Ukraine, supporting domestic and regional tourism in the context of sustainable development) mechanisms (Figure 1).

Thus, the proposed mechanism (Figure 1) as a basic element of innovation management of sustainable tourism, will achieve relevant results and goals 
for the effectiveness of innovation in tourism. The basic principles of the concept of innovation of tourism in the region which is formed according to priorities of regional policy of tourist and innovative development are outlined as a foundation of the mechanism.

The introduction of innovations in the tourism industry will allow to develop an effective tourism policy, which will include the development of

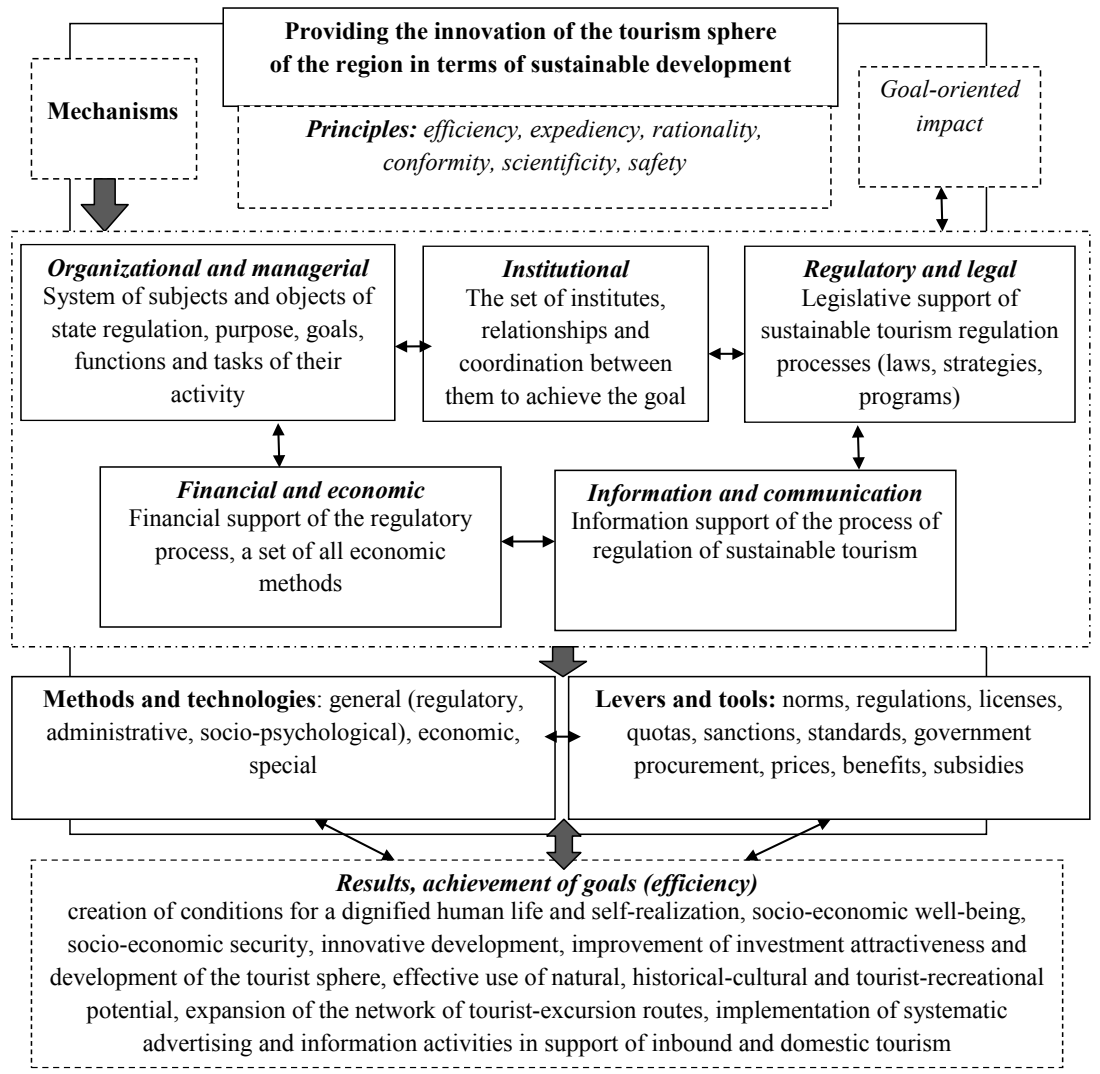

$$
\begin{aligned}
& \text { Figure 1. The structure of the mechanism } \\
& \text { for providing the innovation of the tourism sphere } \\
& \text { in the region in terms of sustainable development }
\end{aligned}
$$

Source: developed by the author based on [6;7] 
strategies and programs for sustainable tourism development; effective use of tourist and recreational potential; formation of personnel and methodical support of tourist activity; organization of festivals, fairs, exhibitions in order to promote Ukraine in international and domestic tourism markets; advertising and information support to improve the image of the country / region; to promote the introduction of innovation and investment activities in the industry; development of tourist infrastructure; to expand international cooperation in the field of tourism; improvement of the system of licensing, certification and standardization of regional tourist services; introduction of statistical accounting and reporting of tourism entities; simplification of customs, currency and tax regulation in tourism, etc.

\section{Assessment of the level of influence of stabilizing and destabilizing factors on the tourist sphere of the region}

Analysis of stabilizing and destabilizing factors of the tourism sphere is the basis for the formation of strategic potential for tourism development in the region and one of the most important prerequisites for transformational changes in the regional tourism system. Assessing the level of impact of these factors, respectively, should be associated with the analysis of current threats and challenges to the security of the regional tourism system, as well as identifying the potential of the tourism sphere in the context of its further development.

Such an assessment can be both quantitative and qualitative, but, in our opinion, a comprehensive approach that involves a comprehensive assessment followed by formalization of its results and calculation of an integrated (general) indicator that characterizes the level of influence of stabilizing and destabilizing factors on tourism sphere of the region in a specific period of time, is more appropriate.

The study of the ratio of the impact of stabilizing and destabilizing factors on the tourism sphere of the regions will identify the main strategic directions and priorities for the transformation of tourism policy, necessary to provide sustainable socio-economic growth of the region and innovative transformations.

The administrative-territorial unit, which is represented by 24 regions (oblasts), has been chosen as the object of the study. The source of information on the choice of primary statistical indicators of socio-economic 
well-being and innovative development of the region in terms of European integration will be the data of the State Statistics Service of Ukraine, which are reflected in the Statistical Collection «Regions of Ukraine» [13].

At the same time, transformational threats and risks are caused not only by Russia's military aggression and political instability in some regions, but also by the complexity and antiquity of infrastructural, social and environmental problems, imbalance of the national economy, asymmetry of the regional landscape, deterioration of criminogenic situation (Table 2).

Table 2

The structure of the integrated index of the level of influence of stabilizing and destabilizing factors on the tourism sphere of the region

\begin{tabular}{|c|c|l|}
\hline No. & Factor & \multicolumn{1}{|c|}{ Name of factor } \\
\hline \multicolumn{3}{|c|}{ Stabilizing factors } \\
\hline 1 & s & Existence of a common border with states the EU states \\
\hline 2 & s & $\begin{array}{l}\text { Number of cultural heritage sites of national importance, units per } \\
\text { thousand sq.km. }\end{array}$ \\
\hline 3 & s & Revenues from the provision of tourist services, UAH per person \\
\hline 4 & s & $\begin{array}{l}\text { Share of persons with higher education in the population aged } 6 \text { and } \\
\text { older, \% }\end{array}$ \\
\hline 5 & s & Share of Ukrainians in the population, \% \\
\hline 6 & s & $\begin{array}{l}\text { Number of foreigners served in collective accommodation facilities } \\
\text { per thousand population }\end{array}$ \\
\hline 7 & s & The share of the region's population aged 25-34,\% \\
\hline 8 & s & $\begin{array}{l}\text { Number of university graduates in tourism specialties, per 100 } \\
\text { thousand people }\end{array}$ \\
\hline 9 & s & Incomes of the population, thousand UAH per person \\
\hline 10 & s & Capital investments in hotel and restaurant business, UAH per person \\
\hline 11 & s & Gross regional product, thousand UAH per person \\
\hline 12 & s & Number of subjects of tourist activity, per 100 thousand people \\
\hline 13 & s & Revenues from the provision of tourist services, UAH per person \\
\hline 14 & s & Revenues from the provision of tourist services, UAH per person \\
\hline 15 & s & $\begin{array}{l}\text { Share of territories and objects of nature reserve fund in the area of } \\
\text { the region, \% }\end{array}$ \\
\hline 16 & s & Share of the region in the all-Ukrainian Internet audience, \% \\
\hline 17 & s & Number of tourism websites, units \\
\hline 18 & s & Provision of the population with hospital beds, per thousand people \\
\hline
\end{tabular}


(End of table 2)

\begin{tabular}{|c|c|l|}
\hline No. & Factor & \\
\hline 19 & s & Provision of the population with doctors, per 100 thousand people \\
\hline 20 & s & Density of paved roads, km per thousand sq.km. \\
\hline 21 & s & Number of operating international airports, units \\
\hline 22 & s & Number of restaurant enterprises, per 100 thousand people \\
\hline 23 & s & $\begin{array}{l}\text { Number of collective accommodation facilities, per 100 thousand } \\
\text { people }\end{array}$ \\
\hline 24 & s & Availability of access to the sea \\
\hline 25 & s & Number of museums, per 100 thousand people \\
\hline & & \multicolumn{2}{|c|}{ Destabilizing factors } \\
\hline 26 & d & $\begin{array}{l}\text { Existence of a common border with the Russian Federation and the } \\
\text { temporarily occupied territories }\end{array}$ \\
\hline 27 & d & Proximity to areas of military-political conflicts \\
\hline 28 & d & Corruption index (according to IER and IIC) \\
\hline 29 & d & Unemployment rate of the population aged 15-70, \% \\
\hline 30 & d & $\begin{array}{l}\text { Number of crimes against public safety, order and morality, } \\
\text { per 100 thousand people }\end{array}$ \\
\hline 31 & d & Number of crimes against property, per 10 thousand people \\
\hline 32 & d & Emissions of pollutants into the atmosphere, per sq.km. \\
\hline 33 & d & Waste generation of 1st-3rdhazard classes, kg per person \\
\hline 34 & d & Number of emergencies, units \\
\hline 35 & d & Morbidity of the population of the region, cases per thousand people \\
\hline 36 & d & Number of road accidents with victims, per 100 thousand people \\
\hline 37 & d & Incidence of diseases of government, per thousand people \\
\hline 38 & d & $\begin{array}{l}\text { The number of fires at enterprises, organizations, institutions, } \\
\text { per 100 thousand people }\end{array}$ \\
\hline
\end{tabular}

Source: composed by the author based on $[5 ; 6 ; 10]$

Of the many methods of standardization used in modern practice and science, standardization based on the ratio of actual factors that characterize the level of influence of stabilizing and destabilizing factors on the tourism sphere of the region to their reference value is the most acceptable [9]. Since the standards of individual properties are absent, the basis for comparing the vector of reference values is the factor of the minimum or maximum values, and the generalized assessment characterizes the degree of deviation of the actual values from the reference. 
For values - stimulants:

$$
z_{i j}=\frac{x_{i j}}{x_{e}}
$$

For values - disincentives:

$$
z_{i j}=\frac{x_{e}}{x_{i j}}
$$

where $(i=1,2, \ldots, m),(j=1,2, \ldots, n)$, where $x_{i j}$ - the value of the $\mathrm{j}$-th indicator;

$x_{e}$ - the value of the standard of the standardized factor;

The obtained standardized values will allow us to calculate the indices of the level of influence of stabilizing and destabilizing factors on the tourism sphere of the region according to the formula [9]:

$$
I_{i j}=\frac{1}{n} \sum_{j=1}^{n} z_{i j}
$$

where $z_{i j}$ - normalized $i$-th value in $j$-th region;

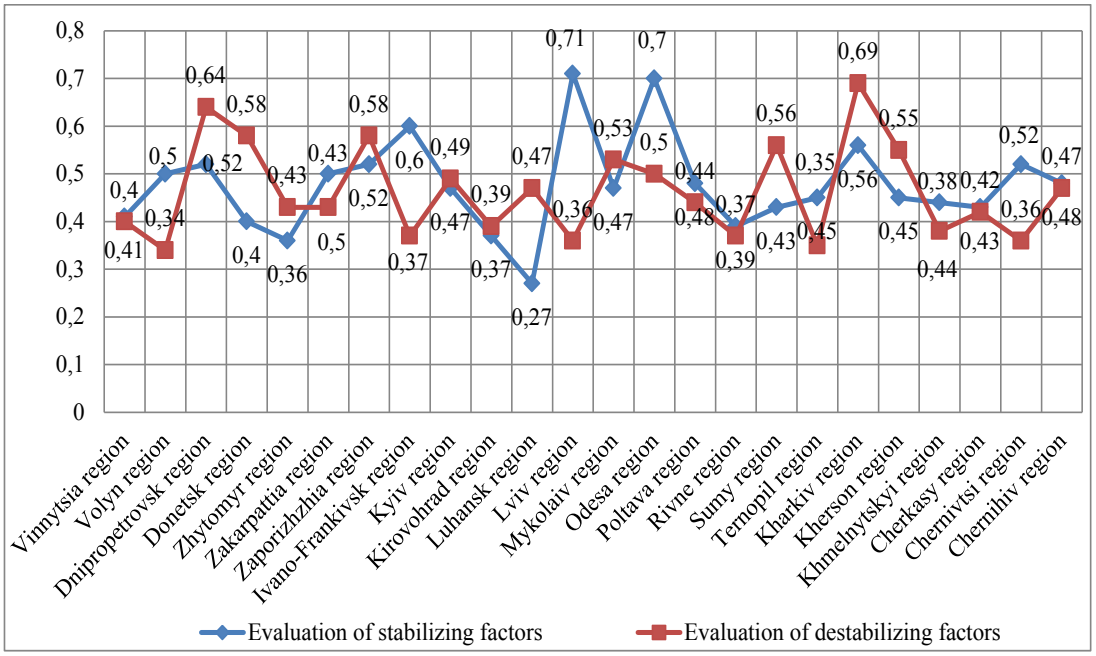

Figure 2. Calculation of integrated indices of the level of influence of stabilizing and destabilizing factors on the tourism sphere of the region in 2018

Source: calculated and developed by the author 
$n$ - the number of indicators that characterize the level of influence of stabilizing or destabilizing factors on the tourism sphere of the region.

Calculations of integrated indices of the level of influence of stabilizing and destabilizing factors on the tourist sphere of the region are given in Figure 2.

\section{Determining the ratio of stabilizing and destabilizing factors in the tourism sphere of the region}

The calculation of the integrated index of the ratio of stabilizing and destabilizing factors in the tourism sphere of the region $\left(\mathrm{I}_{\text {Ссдч }}\right)$ will determine the level of overload of the influence of certain factors. For this purpose the following relations are used:

1) if $I_{\text {ССД }}=\frac{I_{C \Psi}}{I_{\text {ДЧ }}}>1$, the level of influence of stabilizing factors on the tourist sphere of the region prevails over the level of destabilizing;

2) if $I_{\text {ССДЧ }}=\frac{I_{С \Psi}}{I_{Д \Psi}}<1$, the level of influence of destabilizing factors on the tourist sphere of the region prevails over the level of stabilizing;

The value of $\mathrm{I}_{\text {С дч }}=0$ - the extreme critical state of the system, which will be characterized by the state of danger of the tourist sphere of the region, $\mathrm{I}_{\text {ССдч }}>1-$ the ultimate ideal state of the system, which will correspond to the state of security of the tourist sphere of the region. Distribution of the integral index of the ratio of stabilizing and destabilizing factors $\left(\mathrm{I}_{\text {ССдч }}\right)$ for the tourism sphere by region is presented in Figure 3.

To determine the intermediate states that will characterize the integrated index of the ratio of stabilizing and destabilizing factors in the tourism sphere of the region $\left(\mathrm{I}_{\text {Ссдч }}\right.$ ) we use the formula of the so-called "golden section" [9], the essence of which is a proportional ratio close to 0.618 : 0.382 . The laws of the "golden section" are extremely common in wildlife, they are manifested in the harmonious construction of organisms, including humans. Adherence to the dynamic symmetry of the "golden section" determines the most harmonious parameters of structuring the components of the economy, which will contribute to the safest development of the region. This indicates that the possibility of applying the principles of the ratio of "golden section" to determine the state of development of the region seems natural. Therefore, to find the intervals of state

$I_{\text {ССдч }}$ we obtain a quadratic equation: 


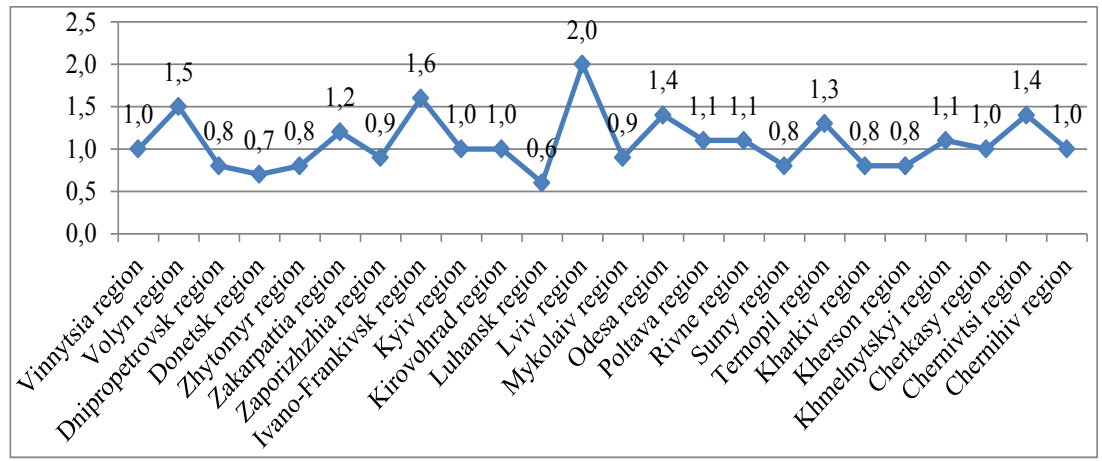

Figure 3. Distribution of the integral index of the ratio of stabilizing

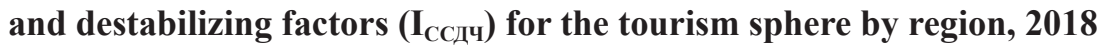
Source: calculated and developed by the authors

$$
x^{2}+a x-a^{2}=0
$$

The solution of which allows to find $\mathrm{x}_{1}$ and $\mathrm{x}_{2}$ :

$$
x_{1,2}=-\frac{a}{2} \pm \sqrt{\frac{a^{2}}{4}+a^{2}},
$$

$\mathrm{x}_{1}=0,383 ; \mathrm{x}_{2}=0,854$.

Thus, the security conditions of the tourist sphere of the region in the period from 0 to 1 will be located as follows - Figure 4 .

Grouping of regions by the level of the ratio of stabilizing and destabilizing factors $\left(\mathrm{I}_{\text {Ссдч }}\right)$ are given in Table 3 .

As we see fom the Table 3, the highest values of the general index of

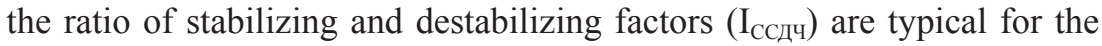
cities of Lviv and Ivano-Frankivsk oblasts. The next group of regions in terms of tourism security is formed by Volyn (1.5), Odesa (1.4), Chernivtsi (1.4), Zakarpattia (1.3), Ternopil (1.2) and Poltava (1.1) oblasts. Vinnytsia (1), Kirovohrad (1), Kyiv (1), Rivne (1), Mykolaiv (0.9), Chernihiv (1) and Cherkasy (1) oblasts have been in the risk group. The threat group includes Dnipropetrovsk (0.8), Zhytomyr (0.8), Sumy (0.8), Kharkiv (0.8) and Kherson (0.8) oblasts. The lowest indicators of the index are observed in Donetsk (0.6) and Luhansk (0.5) oblasts. In the last two groups, in particular, 


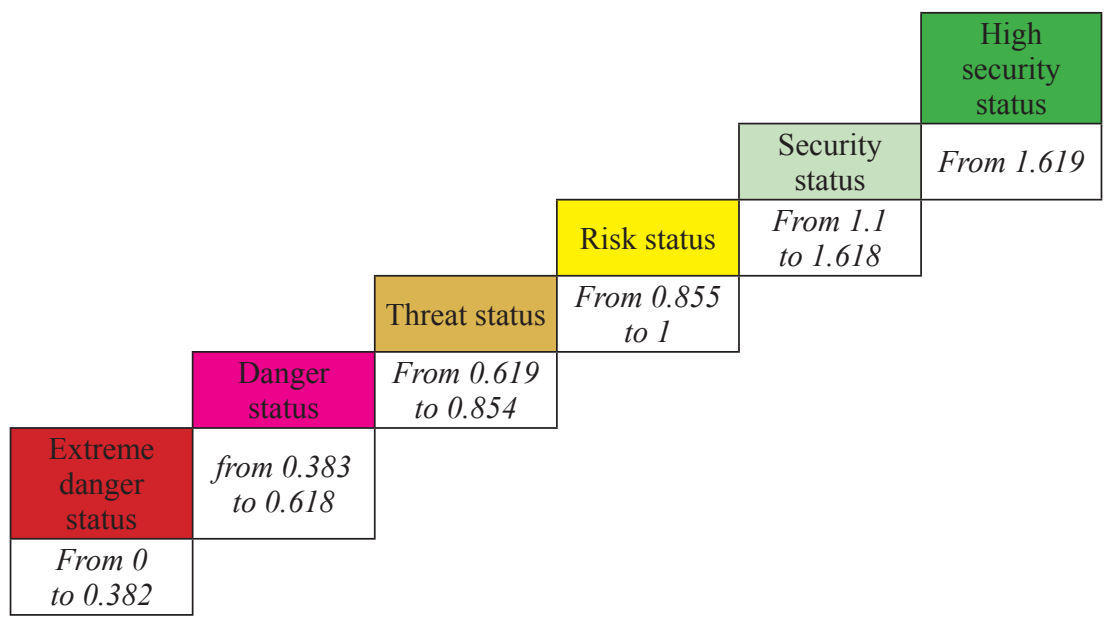

Figure 4. Security status for the development of the tourist sphere of the region

the calculated indicators reach the minimum values, which significantly differ from the average for the state level (1.1). We note that the value of the tourism safety index for Lviv oblast (2) also significantly exceeds the indicator of Ivano-Frankivsk (1.62) oblast, which is in second place.

\section{Evaluation of the effectiveness of the mechanism} for providing the innovation of tourism in the region

The analysis of the grouping of regions by the level of the ratio of stabilizing and destabilizing factors allowed to identify groups of regions by readiness for transformational change. Graphic representation of the selected groups made it possible to identify groups of regions on the basis of transformational changes in the ratio of stabilizing and destabilizing factors in the tourism sphere of the region (ІССДЧ), namely: Security $1.1<\mathrm{I}_{\text {ССдч }}<1.619$, Threat $-1<\mathrm{I}_{\text {Ссдч }}<0.619$, Danger $-0.618<\mathrm{I}_{\text {Ссдч }}<0$.

Transformational changes at the regional level require an effective combination of two interrelated processes - monitoring the state of formation of the mechanism for providing the innovation of tourism in the region, as well as the implementation of program goals and their constant transformation and updating (Figure 4). 
Grouping of regions by the level of the ratio of stabilizing and destabilizing factors $\left(\mathrm{I}_{\text {ССдч }}\right)$

\begin{tabular}{|c|c|}
\hline Intermediate status & Distribution of regions \\
\hline $\begin{array}{l}\text { Extreme danger status } \\
\quad 0<I_{\text {ссдч }}<0.382\end{array}$ & No region \\
\hline \multirow{2}{*}{$\begin{array}{c}\text { Danger } \\
0.383<I_{\text {ССдЧ }}<0.618\end{array}$} & Donetsk (0.6), Luhansk (0.5) \\
\hline & 2 regions \\
\hline \multirow{2}{*}{$\begin{array}{c}\text { Threat } \\
0.619<I_{\text {Ссдч }}<0.854\end{array}$} & $\begin{array}{c}\text { Dnipropetrovsk (0.8), Zhytomyr (0.8), Sumy (0.8), } \\
\text { Kharkiv (0.8), Kherson (0.8) }\end{array}$ \\
\hline & 5 regions \\
\hline \multirow{2}{*}{$\begin{array}{c}\text { Risk } \\
0.855<I_{\text {Ссдч }}<1\end{array}$} & $\begin{array}{l}\text { Vinnytsia (1), Kirovohrad (1), Kyiv (1), } \\
\text { Rivne (1),Mykolaiv (0.9), Chernihiv (1), Cherkasy (1) }\end{array}$ \\
\hline & 7 regions \\
\hline \multirow{2}{*}{$\underset{1.1<I_{\text {Ссдч }}^{\text {Security }}<1.618}{<}$} & $\begin{array}{c}\text { Volyn (1.5), Odesa (1.4), Chernivtsi (1.4), Zakarpattia } \\
\text { (1.3), Ternopil (1.2), Poltava (1.1) }\end{array}$ \\
\hline & 6 regions \\
\hline \multirow{2}{*}{$\begin{array}{c}\text { High security status } \\
I_{\text {ССдЧ }}^{<1.619}\end{array}$} & Lviv (2), Ivano-Frankivsk (1.62) \\
\hline & 2 regions \\
\hline
\end{tabular}

Source: compiled and calculated by the authors

The defined program goals should be the basis of tourism development programs in the regions and provide for the development of specific measures taking into account the spatial specifics (Table 4).

In this context, it is advisable to implement state policy in the field of modernization of regional tourism systems in the following areas:

- reforming the tourism management system;

- diversification of financing of tourism development at the state and local levels;

- coordination of activities of public authorities, local governments, civil society institutions, tourism enterprises and organizations in the direction of realization of competitive advantages;

- monitoring of measures to minimize the impact of threats and risks in the field of tourism;

- deregulation of business activities in the field of tourism business

- improving the training system in accordance with the needs of the market of tourist services;

- intensification of international cooperation in the field of tourism. 


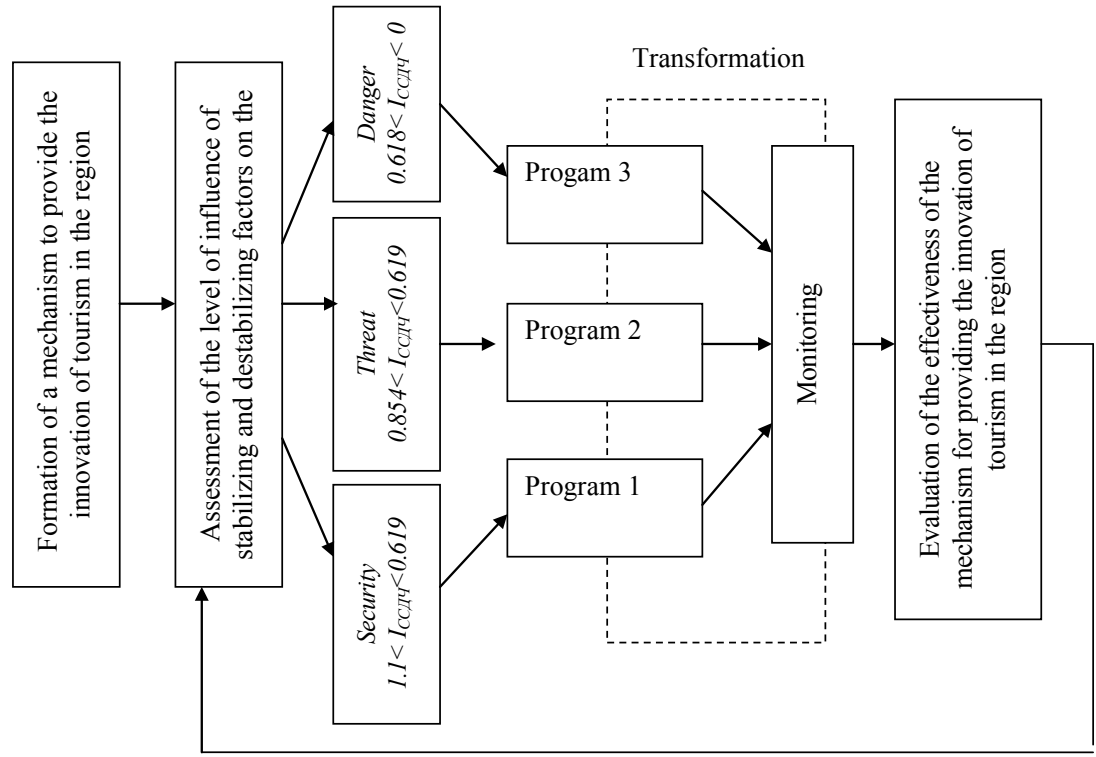

Figure 4. Evaluation of the effectiveness of the mechanism for providing the innovation of tourism in the region

Source: developed by the authors

It should be noted that monitoring the transformation of the tourism sphere in the region is not analogous to monitoring trends in tourism in the region, because it includes a much wider range of parameters that characterize the functioning of all subsystems of a particular regional tourism system. It is clear that such monitoring is most effective at the regional level, and the main function of state executive bodies in the field of tourism in this context should be coordination and rulemaking.

Differentiation of program goals should be based on the results of assessing the modernization potential of tourism development in the regions of Ukraine, as well as on the specifics of strategic priorities for the development of certain components of tourism at the present stage. 


\section{Table 4}

\section{Differentiation of program objectives of development strategies or the regions' tourism}

\begin{tabular}{|c|c|c|}
\hline \multicolumn{3}{|c|}{$\begin{array}{c}\text { The level of the ratio of factors } \\
\text { Program goals }\end{array}$} \\
\hline & $\begin{array}{c}\text { Security } \\
1.1<I_{\text {ССдч }}<0.855\end{array}$ & \\
\hline
\end{tabular}

1) Expanding the representation of tourism enterprises and organizations on the Internet.

2) Providing appropriate conditions for recreational activities on the basis of water bodies of the regions.

3) Strengthening control over the quality and safety of food products in the retail chain and restaurants.

4) Strengthening control by law enforcement agencies over the public safety of tourist destinations.

5) Restriction of traffic on the territory of popular destinations, promotion of cycling and equestrian tourism.

6) Strengthening control over the state of fire safety of tourist enterprises, hotels, restaurants and entertainment establishments

\section{Threat \\ $0.854<I_{\text {ССдЧ }}<0.619$}

1) Intensification of international cooperation in the field of quality assurance and safety of tourist services.

2) Development of an action plan for the restoration of historical and cultural tourist sites and the development of their main competitive tour product.

3) Intensification of promotion of the national tourist product on the international market.

4) Creating favorable conditions for foreign investment in the development of tourist destinations.

5) Stimulation of entrepreneurship in the field of tour business.

6) Development of air transport infrastructure, in particular, opening of new international airports in regional centers.

7) Providing appropriate conditions for recreational activities on the basis of water bodies of the regions.

\section{Danger \\ $0.618<I_{\text {ССдч }}<0$}

1) Intensification of international cooperation in the field of quality assurance and safety of tourist services.

2) Development of an action plan for the restoration of historical and cultural tourist sites and the development of their main competitive tour product.

3) Restoration of national and cultural heritage of the regions and the formation of ethnic tourism destinations.

4) Stimulation of entrepreneurial activity in the field of tourism business.

5) Expansion of the areas of the nature reserve fund and stimulation of its tourist use.

6) Improving the availability and quality of medical services.

7) Stimulation of business activity in hotel business, creation in all destinations of region of establishments of placement of the lowest price category.

8) Stimulating the development of a network of local history and other museums.

9) Stimulating the development of intra-regional children's and youth tourism.

10) Promoting employment growth in tourism.

11) Creating conditions to facilitate the social adaptation of tourists, especially foreign ones, publishing guides, phrasebooks.

Source: developed by the authors 


\section{Conclusions from the study and prospects for further development}

It should be noted that since at the present stage strategic planning in the field of tourism development at the regional level in Ukraine is virtually discontinued, the first stage of development and implementation of strategies for regional tourism systems on the basis of modernization is the restoration of strategic analysis and planning and programming in tourism sphere of regions of Ukraine. Given the specifics of the current stage of development of the state, the basis of such a restoration, in our opinion, should be based on solving the problems of tourism security. The relevance of such problems can be considered as an essential component of the justification of the need to develop and provide the implementation of regional tourism development programs.

In our opinion, in the current conditions of the Ukrainian economy, the following main reasons for ineffective regulation of tourism development in the country are identified: residual and fragmentary financing of tourism from budgetary sources; imperfection and inconsistency of institutional support for tourism development; unformed and unstable mechanisms of tourism management; lack of strategic planning for the development of tourism business in the country and its segmentation at the regional level.

Most of these reasons relate to the regulation of the security component of the transformation processes in the field of tourism, but in this context it is also worth highlighting some specific problems: the non-systemic nature of the organization of tourism insurance in the country; inefficient tourist branding of the state as a whole and its individual regions in the conditions of intensification of military and terrorist threats.

In general, the existing approaches to the improvemennt of regional development strategies obviously need to be adjusted. In particular, in some cases, the allocation of strategic goals related to increasing the tourist attractiveness of the region does not seem entirely justified, along with the inclusion of problems of tourism business development in other components of the strategy. Otherwise, the dispersion of operational goals related to the problems of tourism development between different strategic goals does not allow to develop and apply a comprehensive approach to solving such problems, and does not correlate with the existing structure of regional governance. 
In our opinion, the strategic goal of tourism development transformation should be highlighted in all regional development strategies without exception, and in some regions, where tourism development is a priority, in-depth tourism development strategies should be developed taking into account the transformation paradigm, including its security component and concept of the regional tourist systems. The main principles of developing such strategies should be:

1. Growth of inbound and domestic tourist flows.

2. Improving the image of the regions of the state as favorable for tourism development.

3. Minimization of negative consequences of threats to the safety of tourists and tourist enterprises in the region.

4. Improving the effectiveness of strategic planning and management in the field of tourism in general.

5. Improving the quality of tourist services and improving the quality control system, in particular by government agencies and civil society institutions.

6. Improvement of transport, communal and other infrastructure, improvement of the system of medical services provision.

7. Guaranteeing military-political and public security of tourism in the regions.

8. Improving the system of information support for tourism development.

9. Increasing the financial support of programs and measures for the transformation of the development of the tourism sphere of the region.

\section{References:}

1. Gavran, V. Ya. (2002). Upravlinnya investytsiinoyu diyal'nistyu v rekreatsiino-turystychnii sferi: dys. kand. ekon. nauk [Investment management in recreation and tourism: diss. candidate economic sciences]. Lviv, pp. 122-125.

2. Horina, H. O. (2016). Sutnist ta osoblyvosti typolohii turystychnykh pidpryiemst yak subiektiv upravlinnia [The essence and features of the typology of tourism enterprises as subjects of management]. Naukovyi visnyk Mizhnarodnoho humanitarnoho universytetu, seriya "Ekonomika $i$ menedzhment», vol. 20, pp. 46-49.

3. Davydova, O. H. (2015). Osoblyvosti zastosuvannia innovatsii u rozvytok turystychnoi haluzi Ukrainy [The features of the application of innovation in the tourism industry Ukraine]. Visnyk Kyivskoho natsionalnoho universytetu imeni Tarasa Shevchenka, seriya «Ekonomika», no. 7(172), pp. 65-69. 
4. Ilnytska, H. Ya. (2004). Formuvannia finansovo-ekonomichnoho mekhanizmu upravlinnia pidpryiemstvom [Formation of the financial-economic mechanism of the enterprise's management]. Naukovyi visnyk, Ukrainskyi derzhavnyi lisotekhnichnyi universytet: Zbirnyk naukovo-tekhnichnykh prats, vol. 14.7, pp. 291-294.

5. Lahodiienko, V. V., \& Dovhal, O. V. (2018). Chynnyky ekonomichnoho zrostannia rehioniv v umovakh dysproportsiinosti [Factors of Economic Growth of Regions in Conditions of Disproportionality]. Aktualni problemy innovatsiinoi ekonomiky, no. 3, pp. 15-21.

6. Moisieieva, N. I. (2018). Marketynh yak instrumentarii upravlinnia innovatsiinym rozvytkom turystychnoi sfery rehionu [Marketing as a tool for managing the innovative development of the tourism industry in the region]. Prychornomorski ekonomichni studii, vol. 34, pp. 220-222.

7. Moklyak, A. (2004). Turysts'ki resursy dlya potreb inozemnogo turyzmu v Ukraini (v konteksti ukrains'ko-pol's'kykh turystychnykh zv'yazkiv): dys. kand. geogr. nauk [Tourist resources for the needs of foreign tourism in Ukraine (in the context of Ukrainian-Polish tourist relations): dyss. candidate geograph. sciences]. Kyiv, pp. 100-101.

8. Orlenko, Ya. Yu. (2016). Imperatyvy rozvytku turystychnoi haluzi Ukrainy [The imperatives of the development of tourist industry of Ukraine]. Visnyk Natsionalnoho universytetu tsyvilnoho zakhystu Ukrainy, seriia «Derzhavne upravlinnia», vol. 2, pp. 25-36.

9. Trillenberh, H. (2014). Innovatsiino-klasternyi pidkhid do rozvytku turyzmu Ukrainy v umovakh hlobalizatsii [Innovation-cluster approach to the development of tourism in Ukraine under the conditions of globalization]. Zhurnal yevropeiskoi ekonomiky, t. 13, no. 4, pp. 401-414.

10. Tsyhlyki, I. (2000). Vnutrishniiekonomichnyimekhanizmpidpryiemstva [Internal economic mechanism of the enterprise]. Ivano-Frankivsk: IME, $104 \mathrm{p}$.

11. Svitovyy atlas danykh [World Data Atlas]. Retrieved from: https://knoema.ru/ atlas (accessed 14 January 2020).

12. The Travel \& Tourism Competitiveness Report. Retrieved from: http://www3.weforum.org/docs/WEF_TTCR_2019.pdf (accessed 14 January 2020). 